\title{
Intraspecific Phylogenetic Relationships of Caryopteris incana in the Tsushima Islands, Japan, Using DNA Sequence Analysis
}

\author{
Masaya Ando1, Hitoshi Watanabe ${ }^{2 *}$, Kiyoshi Matsubara ${ }^{2}$, Akito Taniguchi ${ }^{3}$ \\ ${ }^{1}$ Graduate School of Horticulture, Chiba University, Matsudo, Japan \\ ${ }^{2}$ Center for Environment, Health and Field Sciences, Chiba University, Kashiwa, Japan \\ ${ }^{3}$ Faculty of Horticulture, Chiba University, Matsudo, Japan \\ Email: ${ }^{*}$ hwatanabe@faculty.chiba-u.jp
}

Received 24 August 2015; accepted 20 September 2015; published 23 September 2015

Copyright (C) 2015 by authors and Scientific Research Publishing Inc.

This work is licensed under the Creative Commons Attribution International License (CC BY). http://creativecommons.org/licenses/by/4.0/

(c) (i) Open Access

\begin{abstract}
Caryopteris incana is a perennial shrub distributed in the temperate zone of the East Asia. It is found in West Kyushu in Japan, where it is designated as an endangered species. Tsushima, Nagasaki, which experienced repeated connection and fragmentation between the Korean Peninsula and Japan, is an island on the route along which $C$. incana moved to Japan from continental Asia. We conducted field work and confirmed the genetic structure of populations using DNA sequence analysis to construct a detailed distribution map and clarify the intraspecific phylogenetic relationships of $C$. incana in Tsushima Island. We confirmed 72 populations in Tsushima. Using the leaves of individuals cultivated from seeds collected from each natural population, we analyzed the chloroplast and nuclear DNA sequence variations. Among the populations, sequence variations were confirmed in six regions of chloroplast DNA, and six haplotypes, including base substitutions, were distinguished. Two haplotypes were mainly divided at the border of the northern part of the southern island in Tsushima. One population in the northwestern part of the north island showed a haplotype derived from the southern part. This finding revealed that the distribution of $C$. incana had been artificially influenced. Several haplotypes were confirmed by sequence variations in the northern populations, but only one haplotype in the southern populations, suggesting that $C$. incana on the north island had separated early from the south island in Tsushima.
\end{abstract}

\section{Keywords}

Caryopteris incana, Intraspecific Differentiation, Sequence Variation, Chloroplast DNA, ITS

\footnotetext{
${ }^{*}$ Corresponding author.

How to cite this paper: Ando, M., Watanabe, H., Matsubara, K. and Taniguchi, A. (2015) Intraspecific Phylogenetic Relationships of Caryopteris incana in the Tsushima Islands, Japan, Using DNA Sequence Analysis. American Journal of Plant Sciences, 6, 2361-2373. http://dx.doi.org/10.4236/ajps.2015.614239
} 


\section{Introduction}

The distribution and variation of the existing organisms are the results of the accumulated effects of past population dynamics and evolutionary history. By obtaining effective characteristics via adaption to the local environment after expansion to a new location, the organisms will undergo speciation or intraspecific differentiation [1]. Biogeography is the study of the history of the organisms by considering the variations in their characteristics and environmental changes. The field focuses, in particular, on genetic variation in phylogeography, and has been used to examine various species worldwide in order to clarify the evolutionary history of organisms that have survived the glacial and interglacial periods over the past tens of thousands to millions of years [2]-[5]. The islands of Japan, located in East Asia, are a hotspot for immigration to, and emigration from, continental Asia, and, similar to the Mediterranean region, there has been repeated connection and fragmentation of lands over glacial and interglacial periods [6]-[8].

The Japanese Islands extend north and south; have wide climatic variation, from a southern subtropical zone to a north subarctic zone; and have maintained various endemic species in refugia where they avoided extinction during glacial periods. Further, there have been repeated invasions of organisms from the continent because of land connections with the continent during glacial periods [9]. After the formation of each land bridge, many areas were geographically isolated by the subsequent rising sea level; for instance, many endemic species inhabit the Yakushima Island, which is famous for the Yaku cedar. Among these regions, the islands of Tsushima, Nagasaki, have a mixed flora of species originating from the continent and from Japan as a result of the immigration and emigration of organisms with mainland Asia, because the Korean Peninsula and Tsushima were repeatedly connected and fragmentation by land [10]. Tsushima, Nagasaki, a continental island located northwest of Kyushu, extends $18 \mathrm{~km}$ from east to west and $82 \mathrm{~km}$ from north to south and has an area of approximately $700 \mathrm{~km}^{2}$ (Figure 1). It is approximately $50 \mathrm{~km}$ from the northwest of Tsushima to the Korean Peninsula, and approximately $132 \mathrm{~km}$ from the southeast of Tsushima to the Kyushu mainland. It has an oceanic climate with only small changes in temperature because of the Tsushima Current, but it is cool in the winter because of the northwest monsoon. Most of the islands consist of sedimentary rock rich in mud from the Tertiary, called the Taishu group. The islands are divided into the north and south, and a rias coast develops in the shoreline around the central region. The flora of Tsushima consists of the template plants from southern Japan, continental plant, and subtropical and tropical plants expanding their distribution to the north [9] [11]. Some continental plant species have expanded their distribution to Kyushu and West Japan through Tsushima, and the intraspecific and interspecific genetic differences between the Japanese Islands, the Korean Peninsula, and Tsushima, which is a halfway point between the two, are important phylogeographical indices when considered along with the geological history and paleontology of these areas [10]. Caryopteris incana (Thunb.) Miq. is one such species of continental plant.

Caryopteris is a genus of shrubs or subshrubs of the family Lamiaceae that is distributed in China, Mongolia, Tibet, Taiwan, Korea, and Japan. The terminal corymboid cymes have pedicellate ebracteate flowers, and
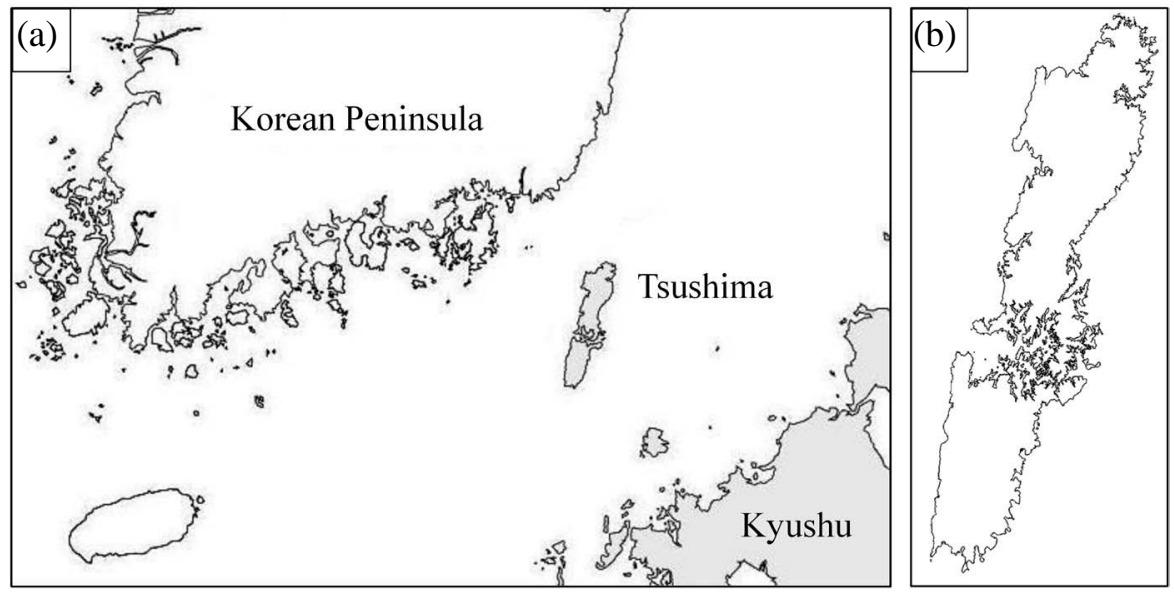

Figure 1. Map showing the location of the study area. (a) Geographical location of Tsushima, Japan. (b) Outline of Tsushima. 
the corollas are bluish purple or pale green to yellowish. The leaves are strongly aromatic. The familial assignment and infrageneric classification of Caryopteris were determined based on their floral, fruit, and pollen morphology [12] and on phylogenetic analysis [13]. Caryopteris comprises seven species at present. Caryopteris incana is a perennial herb, shrub, or subshrub that is distributed in China, the Korean Peninsula, and Japan. Lavender-blue, cymose flowers in the axils of the opposite leaves appear naturally from late summer to fall and continue to flower for one to two months. C. incana is cultivated for use in flower arrangements and gardens. The hybrid cultivar $C$. $\times$ clandonensis $(C$. incana $\times C$. mongolica Bunge) has a variety of superior properties. As a medicinal ingredient, all parts of $C$. incana include several kinds of phenylpropanoid glycosides, and it is used as a medicinal herb in China [14]-[18]. In addition, its essential oil extract has been reported to have an insecticidal effect [19]. Its distribution in the Japanese Islands is limited to West Kyushu, and it grows wild in the Kyushu mainland, the Goto Islands of Nagasaki, and the Koshiki Islands of Kagoshima, and, in particular, Tsushima is assumed to be a center of its distribution [20] [21]. C. incana grows wild mainly on sunny bare rock. This species may grow with Selaginella tamariscina, which likes similar environment. Populations of $C$. incana have decreased because of development and infrastructure maintenance around its natural habitat, and it has been designated as endangered species, listed as "vulnerable" in Japan [22]. However, detailed fieldwork related to C. incana in West Kyushu has not been conducted since 1988 [20].

We performed this study along two purposes: to construct a detailed distribution map for Tsushima, which is a center of the distribution of $C$. incana, an endangered species; and to determine the genetic structure using the DNA sequence of populations in Tsushima and to compare this with the geographical structure. These results would offer useful information for determining the evolutionary history of $C$. incana in Tsushima and for devising a conservation plan.

\section{Materials and Methods}

\subsection{Field Work}

We investigated all of Tsushima based on the report by [20] to confirm six locations of exposed rock where $C$. incana would be expected to grow. In this article, when groups of individuals were separated by more than $2 \mathrm{~km}$, we defined each as a different "population". We recorded environmental data, such as the latitude/longitude, altitude, population area, and numbers of individual in each natural population. In addition, for the genetic investigation of each population, we collected seeds from mature individuals in all population. We performed the statistical analysis of environmental data by comparing with shore and inland populations using the Student's t-test in SPSS.

\subsection{Sampling and DNA Extraction}

We planted the seeds from the natural populations and grew them under the same conditions in a greenhouse. We transplanted seeds into seven bowls and managed the plants in a non-temperate/climate controlled environment from June to July after planting in April 2013. The growth medium consisted of red soil: peat moss: perlite $=$ 7:2:1 without basal fertilizer. Fresh young leaves were gathered from each individual and were kept at $-80^{\circ} \mathrm{C}$ until DNA extraction. Genomic DNA was extracted by the modified cetyltrimethylammonium bromide (CTAB) method [23] [24]. We adjusted extraction DNA to a concentration of $100 \mathrm{ng} / \mu \mathrm{l}$ by a spectrum altimeter and used polymerase chain reaction (PCR). We used a sample of one or two individuals for the chloroplast DNA sequence analysis, and a bulk sample, which mixed DNA of the same concentration that we extracted and adjusted from 10 individuals for the nuclear DNA sequence analysis.

\subsection{DNA Sequence Analyses}

To investigate the chloroplast DNA sequence, We used three regions that were registered in Genbank in C. incana that were suitable for the phylogenetic analysis and were more subtle than variation within the genus; matK [25] [26], trnL-trnF [27] [28], and rpl32-trnL [29] [30]. The Genbank accession numbers of matK, trnLtrnF, and rpl32-trnL are AF315295, JF301359, and JQ669280 respectively. Therefore, we chose eight intergenic spacer sequences that were determined to be suitable for the classification of closely related species by [29]: trnQ-rps16, atpI-atpH, ndhF-rpl32, petL-psbE, psbD-trnT, psbJ-petA, rps16-trnK, and trnV-ndhC. On the other hand, we used the ITS [31]-[33] of the Genbank registration sequence for the nuclear DNA sequence. The Gen- 
bank accession number of the ITS is EF508064. Each primer was prepared from the original paper or sequence information newly in Genbank registration regions, and universal primers were used in the remaining regions (Table 1). The PCR solution was adjusted according to the instruction of the KAPA extra Taq kit (NIPPON Genetics). All reactions were performed with the following program using a Veriti Thermal Cycler (Life technologies): initial denaturation for $2 \mathrm{~min}$ at $95^{\circ} \mathrm{C}$; 35 cycles of $20 \mathrm{~s}$ at $95^{\circ} \mathrm{C}, 15 \mathrm{~s}$ of annealing at $50^{\circ} \mathrm{C}$ for all the chloroplast regions and $56^{\circ} \mathrm{C}$ for the ITS region, and 1 or $2 \mathrm{~min}$ at $68^{\circ} \mathrm{C}$; a final extension for $2 \mathrm{~min}$ at $68{ }^{\circ} \mathrm{C}$; and kept at $4^{\circ} \mathrm{C}$ until further processing. The amplification was confirmed by agarose gel electrophoresis. PCR products were purified using ExoSAP-IT (GE), which reacted for $30 \mathrm{~min}$ at $37^{\circ} \mathrm{C}, 15 \mathrm{~min}$ at $80^{\circ} \mathrm{C}$. Sequencing reactions were performed using a Bigdye ${ }^{\mathrm{TM}}$ Terminator v3.1 Cycle Sequencing Kit (Life technologies), and gel filtration was performed for each sample. Sequences were analyzed in a 3500 Genetic Analyzer (Life technologies).

\subsection{Phylogenetic Analyses}

The base sequences of each population were aligned using the BioEdit software (version 7.2.5) and compared with the registration sequences in the Genbank registration region [34]. Phylogenetic trees were constructed by the neighbor-joining method using the Kimura 2-parameter model in MEGA 6 [35]. The reliability of the topology was assessed with the bootstrap analysis by 1000 replications. Tripora divaricate (Maxim.) P.D. Cantino, which is a related genus of Caryopteris, was included as an outgroup in the phylogenetic analysis. The network figure was drawn using the SplitsTree 4.0 software package [36].

Table 1. Primer names and sequences for the amplification and cycle sequencing of chloroplast and nuclear DNA.

\begin{tabular}{|c|c|c|c|}
\hline region & primer name & primer sequence $^{a}$ & reference \\
\hline \multirow{2}{*}{ matK } & MG1 & 5'-CTACTGCAGAACTAGTCGGATGGAGTAGAT-3' & Hilu et al., 1997 \\
\hline & MG15 & 5'-ATCTGGGTTGCTAACTCAATG-3' & Hilu et al., 1997 \\
\hline \multirow{2}{*}{ trnL-trnF } & c & 5'-CGAAATCGGTAGACGCTACG-3' & Taberlet et al.,1991 \\
\hline & $\mathrm{f}$ & 5'-ATTTGAACTGGTGACACGAG-3' & Taberlet et al.,1991 \\
\hline \multirow{2}{*}{ rpl32-trnL } & rpL32-F & 5'-CAGTTCCAAAAAAACGTACTTC-3' & Shaw et al., 2007 \\
\hline & $\operatorname{trn} L^{(\mathrm{UAG})}$ & 5'-CTGCTTCCTAAGAGCAGCGT-3' & Shaw et al., 2007 \\
\hline \multirow{2}{*}{$\operatorname{trnQ}-r p s 16$} & $\operatorname{trn} Q^{(U U G)}$ & 5'-GCGTGGCCAAGYGGTAAGGC-3' & Shaw et al., 2007 \\
\hline & $\operatorname{rpS} 16 \times 1$ & 5'-GTTGCTTTYTACCACATCGTTT-3' & Shaw et al., 2007 \\
\hline \multirow{2}{*}{$a t p \mathrm{I}-a t p \mathrm{H}$} & atpI & 5'-TATTTACAAGYGGTATTCAAGCT-3' & Shaw et al., 2007 \\
\hline & atpH & 5'-CCAAYCCAGCAGCAATAA C-3' & Shaw et al., 2007 \\
\hline \multirow{2}{*}{ ndhF-rpl32 } & ndhF & 5'-GAAAGGTATKATCCAYGMATATT-3' & Shaw et al., 2007 \\
\hline & rpL32-R & 5'-ССААТАТСССТТYҮТТТТССАА-3' & Shaw et al., 2007 \\
\hline \multirow{2}{*}{ petL-psbE } & petL & 5'-AGTAGAAAACCGAAATAACTAGTTA-3' & Shaw et al., 2007 \\
\hline & psbE & 5'-TATCGAATACTGGTAATAATATCAGC-3' & Shaw et al., 2007 \\
\hline \multirow{2}{*}{$p s b \mathrm{D}-t r n \mathrm{~T}$} & psbD & 5'-CTCCGTARCCAGTCATCCATA-3' & Shaw et al., 2007 \\
\hline & $\operatorname{trnT}^{(\mathrm{GGU})}-\mathrm{R}$ & 5'-CCСTTTTAACTCAGTGGTAG-3' & Shaw et al., 2007 \\
\hline \multirow{2}{*}{ psbJ-petA } & psbJ & 5'-ATAGGTACTGTARCYGGTATT-3' & Shaw et al., 2007 \\
\hline & petA & 5'-AACARTTYGARAAGGTTCAATT-3' & Shaw et al., 2007 \\
\hline \multirow{2}{*}{ rps16-trnK } & $\mathrm{rpS} 16 \times 2 \mathrm{~F} 2$ & 5'-AAAGTGGGTTTTTATGATCC-3' & Shaw et al., 2007 \\
\hline & $\operatorname{trn} K^{(\mathrm{UUU})} \times 1$ & 5'-TTAAAAGCCGAGTACTCTACC-3' & Shaw et al., 2007 \\
\hline \multirow{2}{*}{$\operatorname{trnV}-n d h \mathrm{C}$} & $\operatorname{trn} \mathrm{V}^{(\mathrm{UAC})} \times 2$ & 5'-GTCTACGGTTCGARTCCGTA-3' & Shaw et al., 2007 \\
\hline & ndhC & 5'-TATTATTAGAAATGYCCARAAAATATCATATTC-3' & Shaw et al., 2007 \\
\hline \multirow{2}{*}{ ITS } & ITS1 & 5'-GTCCACTGAACCTTATCATTTAG-3' & White et al., 1990 \\
\hline & ITS4 & 5'-TCCTCCGCTTATTGATATGC-3' & White et al., 1990 \\
\hline
\end{tabular}

${ }^{\mathrm{a}} \mathrm{K}=\mathrm{G}$ or $\mathrm{T}, \mathrm{R}=\mathrm{A}$ or $\mathrm{G}, \mathrm{Y}=\mathrm{C}$ or $\mathrm{T}$. 


\section{Results and Discussion}

\subsection{Local Environments}

From our field work, we confirmed 72 natural populations in 111 locations throughout Tsushima that were suitable for the growth of $C$. incana (Figure 2). In agreement with the report of [20], it seems to be widely distributed in each place over the islands. We confirmed that $C$. incana grew locally on open rocky sites, such as roadsides, mountains, and shorelines. In such places, it grew wild while avoiding competition with plants at some environments, such as gaps in a natural forest, artificial rocky places by infrastructure maintenance, gaps in concrete surfaces, and bare rock places facing the sea. There were few individuals of $C$. incana on rocky places covered by creeping vines. Natural populations were not confirmed on rock surfaces along the shore exposed to strong winds, and there were many individuals in inlets. Thus, natural populations of $C$. incana tended to be locally discontinuous. In addition, populations were confirmed near the slope faces for greening along roadside, and it is possible that their presence at such locations was affected by human activities, such as planting.

There were 39 populations near shores at around $20 \mathrm{~m}$ from the sea, and the average altitude in these locations was $5.6 \pm 1.4 \mathrm{~m}$ above the high tide line (Table 2). On the other hand, there were 33 populations on mountains or small inlands, and the average altitude of these locations was $47.7 \pm 6.3 \mathrm{~m}$, covering a wider range than shore populations. There were 22 populations on the south island, at an average altitude of $38.2 \pm 8.8 \mathrm{~m}$, and 50 populations on the north island, at an average altitude of $19.0 \pm 3.6 \mathrm{~m}$. It was thought that these values were due to higher altitudes and a higher ratio of inland populations on the south island than on the north island, but there were few populations in the center of either island. In addition, the number of individuals in populations along

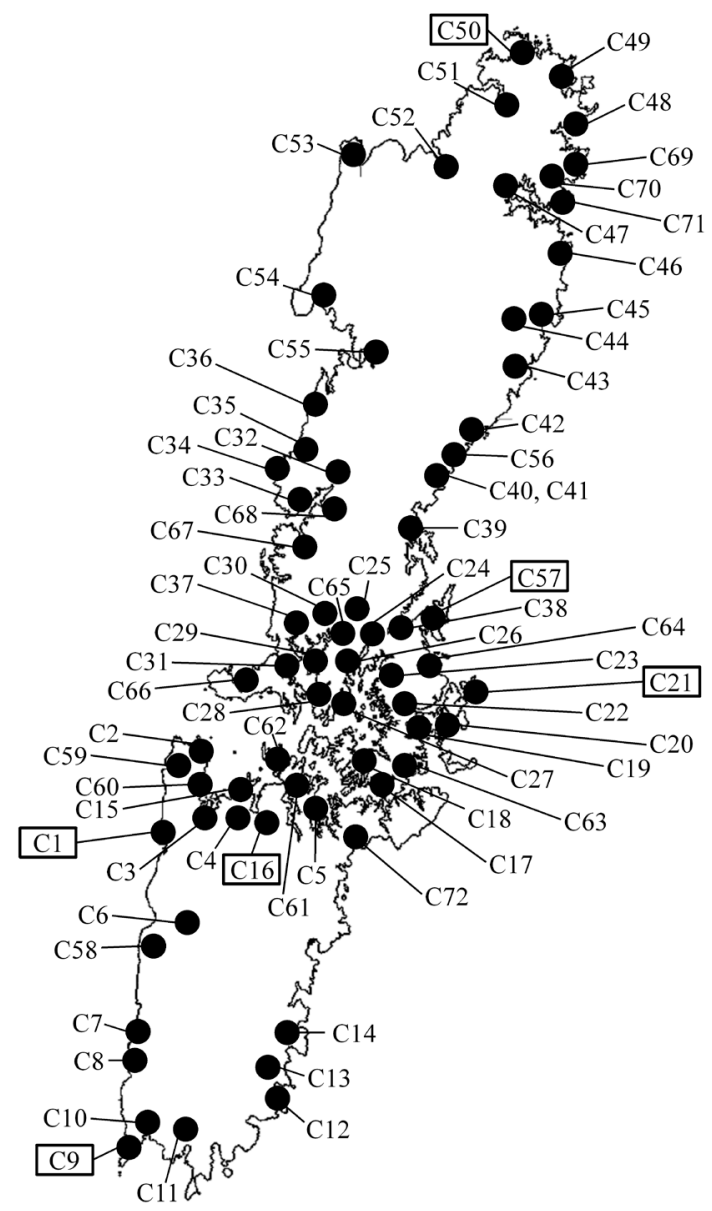

Figure 2. Geographic distribution of $C$. incana in tsushima. Black circles indicate each population. Numbers label different populations. Boxed labels indicate populations reported by [20]. 
Table 2. The latitude, longitude, altitude, area, and number of individuals of study populations in C. incana.

\begin{tabular}{|c|c|c|c|c|c|}
\hline population & north latitude & east longitude & altitude (m) & population area $\left(\mathrm{m}^{2}\right)$ & number of individuals \\
\hline $\mathrm{C} 1$ & $34^{\circ} 16^{\prime} 26^{\prime \prime}$ & $129^{\circ} 12^{\prime} 31^{\prime \prime}$ & 75 & 675 & 67 \\
\hline $\mathrm{C} 2$ & $34^{\circ} 19^{\prime} 5^{\prime \prime}$ & $129^{\circ} 13^{\prime} 42^{\prime \prime}$ & 4 & 60 & 9 \\
\hline $\mathrm{C} 3$ & $34^{\circ} 17^{\prime} 34^{\prime \prime}$ & $129^{\circ} 14^{\prime} 3^{\prime \prime}$ & 66 & 79.5 & 14 \\
\hline $\mathrm{C} 4$ & $34^{\circ} 17^{\prime 2} 28^{\prime \prime}$ & $129^{\circ} 15^{\prime} 28^{\prime \prime}$ & 2 & over $^{\mathrm{a}}$ & over $^{b}$ \\
\hline C5 & $34^{\circ} 17^{\prime} 30^{\prime \prime}$ & $129^{\circ} 18^{\prime} 6^{\prime \prime}$ & 5 & 1410 & 46 \\
\hline C6 & $34^{\circ} 13^{\prime} 46^{\prime \prime}$ & $129^{\circ} 13^{\prime} 4^{\prime \prime}$ & 16 & 1305 & 51 \\
\hline C7 & $34^{\circ} 10^{\prime} 3^{\prime \prime}$ & $129^{\circ} 10^{\prime} 38^{\prime \prime}$ & 4 & 4 & 2 \\
\hline $\mathrm{C} 8$ & $34^{\circ} 9^{\prime} 29^{\prime \prime}$ & $129^{\circ} 10^{\prime} 37^{\prime \prime}$ & 59 & 272 & 29 \\
\hline C9 & $34^{\circ} 6^{\prime} 48^{\prime \prime}$ & $129^{\circ} 10^{\prime} 30^{\prime \prime}$ & 96 & over & over \\
\hline C10 & $34^{\circ} 6^{\prime} 56^{\prime \prime}$ & $129^{\circ} 10^{\prime} 36^{\prime \prime}$ & 96 & 22.5 & 230 \\
\hline C11 & $34^{\circ} 7^{\prime} 12^{\prime \prime}$ & $129^{\circ} 13^{\prime} 5^{\prime \prime}$ & 77 & 20 & 16 \\
\hline $\mathrm{C} 12$ & $34^{\circ} 8^{\prime} 18^{\prime \prime}$ & $129^{\circ} 16^{\prime} 22^{\prime \prime}$ & 68 & 175 & 83 \\
\hline $\mathrm{C} 13$ & $34^{\circ} 8^{\prime} 47^{\prime \prime}$ & $129^{\circ} 16^{\prime} 34^{\prime \prime}$ & 4 & 4 & 3 \\
\hline C14 & $34^{\circ} 9^{\prime} 56^{\prime \prime}$ & $129^{\circ} 17^{\prime \prime}{ }^{\prime \prime}$ & 6 & 5 & 9 \\
\hline C15 & $34^{\circ} 18^{\prime} 1 "$ & $129^{\circ} 15^{\prime} 8^{\prime \prime}$ & 3 & 26 & 15 \\
\hline C16 & $34^{\circ} 17^{\prime} 25^{\prime \prime}$ & $129^{\circ} 15^{\prime} 43^{\prime \prime}$ & 1 & 13 & 65 \\
\hline C17 & $34^{\circ} 18^{\prime} 35^{\prime \prime}$ & $129^{\circ} 21^{\prime} 10^{\prime \prime}$ & 7 & over & over \\
\hline C18 & $34^{\circ} 19^{\prime} 4^{\prime \prime}$ & $129^{\circ} 20^{\prime} 17^{\prime \prime}$ & 21 & over & over \\
\hline C19 & $34^{\circ} 20^{\prime} 15^{\prime \prime}$ & $129^{\circ} 22^{\prime} 12^{\prime \prime}$ & 4 & 16 & 7 \\
\hline C20 & $34^{\circ} 20^{\prime} 21^{\prime \prime}$ & $129^{\circ} 23^{\prime 2} 29^{\prime \prime}$ & 4 & over & over \\
\hline C21 & $34^{\circ} 21^{\prime} 10^{\prime \prime}$ & $129^{\circ} 24^{\prime} 20^{\prime \prime}$ & 2 & 80 & 40 \\
\hline $\mathrm{C} 22$ & $34^{\circ} 20^{\prime} 46^{\prime \prime}$ & $129^{\circ} 21^{\prime} 53^{\prime \prime}$ & 3 & 720 & 87 \\
\hline C23 & $34^{\circ} 22^{\prime} 23^{\prime \prime}$ & $129^{\circ} 21^{\prime \prime} 9^{\prime \prime}$ & 1 & 10 & 27 \\
\hline $\mathrm{C} 24$ & $34^{\circ} 23^{\prime} 0^{\prime \prime}$ & $129^{\circ} 20^{\prime} 32^{\prime \prime}$ & 13 & 2100 & over \\
\hline $\mathrm{C} 25$ & $34^{\circ} 23^{\prime} 2^{\prime \prime}$ & $129^{\circ} 19^{\prime} 43^{\prime \prime}$ & 37 & 100 & 9 \\
\hline C26 & $34^{\circ} 21^{\prime} 58^{\prime \prime}$ & $129^{\circ} 19^{\prime} 11^{\prime \prime}$ & 15 & 192 & 49 \\
\hline C27 & $34^{\circ} 20^{\prime} 56^{\prime \prime}$ & $129^{\circ} 18^{\prime} 57^{\prime \prime}$ & 10 & 50 & 20 \\
\hline C28 & $34^{\circ} 21^{\prime} 0^{\prime \prime}$ & $129^{\circ} 18^{\prime} 41^{\prime \prime}$ & 32 & 1 & 1 \\
\hline C29 & $34^{\circ} 21^{\prime} 45^{\prime \prime}$ & $129^{\circ} 18^{\prime} 32^{\prime \prime}$ & 62 & 2 & 3 \\
\hline C30 & $34^{\circ} 23^{\prime 2}{ }^{\prime \prime}$ & $129^{\circ} 18^{\prime} 54^{\prime \prime}$ & 40 & 2 & 6 \\
\hline C31 & $34^{\circ} 21^{\prime} 57^{\prime \prime}$ & $129^{\circ} 16^{\prime} 44^{\prime \prime}$ & 3 & 2870 & 131 \\
\hline C32 & $34^{\circ} 27^{\prime} 52^{\prime \prime}$ & $129^{\circ} 18^{\prime} 53^{\prime \prime}$ & 3 & 768 & over \\
\hline C33 & $34^{\circ} 27^{\prime} 26^{\prime \prime}$ & $129^{\circ} 17^{\prime} 57^{\prime \prime}$ & 3 & 17.5 & 15 \\
\hline C34 & $34^{\circ} 28^{\prime} 16^{\prime \prime}$ & $129^{\circ} 16^{\prime} 56^{\prime \prime}$ & 17 & 126 & 10 \\
\hline C35 & $34^{\circ} 29^{\prime} 7 "$ & $129^{\circ} 17^{\prime} 47^{\prime \prime}$ & 122 & 1482 & 163 \\
\hline C36 & $34^{\circ} 30^{\prime} 37^{\prime \prime}$ & $129^{\circ} 18^{\prime} 7^{\prime \prime}$ & 2 & 1 & 3 \\
\hline C37 & $34^{\circ} 23^{\prime} 15^{\prime \prime}$ & $129^{\circ} 17^{\prime} 18^{\prime \prime}$ & 5 & 8 & 20 \\
\hline C38 & $34^{\circ} 23^{\prime} 33^{\prime \prime}$ & $129^{\circ} 21^{\prime} 22^{\prime \prime}$ & 2 & 1230 & 125 \\
\hline C39 & $34^{\circ} 26^{\prime} 8^{\prime \prime}$ & $129^{\circ} 22^{\prime} 1 "$ & 7 & over $^{\mathrm{a}}$ & over $^{\mathrm{b}}$ \\
\hline C40, C41 & $34^{\circ} 28^{\prime} 30^{\prime \prime}$ & $129^{\circ} 23^{\prime} 26^{\prime \prime}$ & 12 & over & over \\
\hline C42 & $34^{\circ} 29^{\prime} 31^{\prime \prime}$ & $129^{\circ} 24^{\prime} 7^{\prime \prime}$ & 51 & over & over \\
\hline C43 & $34^{\circ} 31^{\prime} 17^{\prime \prime}$ & $129^{\circ} 26^{\prime} 4^{\prime \prime}$ & 40 & over & over \\
\hline C44 & $34^{\circ} 33^{\prime} 5^{\prime \prime}$ & $129^{\circ} 27^{\prime \prime} 3^{\prime \prime}$ & 55 & 370 & 53 \\
\hline
\end{tabular}




\begin{tabular}{|c|c|c|c|c|c|}
\hline \multicolumn{6}{|c|}{ Continued } \\
\hline C45 & $34^{\circ} 33^{\prime} 10^{\prime \prime}$ & $129^{\circ} 27^{\prime} 33^{\prime \prime}$ & 4 & 4 & 7 \\
\hline C46 & $34^{\circ} 35^{\prime} 54^{\prime \prime}$ & $129^{\circ} 28^{\prime} 27^{\prime \prime}$ & 10 & over & 7 \\
\hline C47 & $34^{\circ} 37^{\prime} 37^{\prime \prime}$ & $129^{\circ} 26^{\prime} 37^{\prime \prime}$ & 8 & 750 & 41 \\
\hline C48 & $34^{\circ} 39^{\prime} 28^{\prime \prime}$ & $129^{\circ} 28^{\prime} 51^{\prime \prime}$ & 7 & 195 & 75 \\
\hline C49 & $34^{\circ} 40^{\prime} 57^{\prime \prime}$ & $129^{\circ} 28^{\prime} 20^{\prime \prime}$ & 20 & 1 & 1 \\
\hline C50 & $34^{\circ} 41^{\prime} 40^{\prime \prime}$ & $129^{\circ} 26^{\prime} 21^{\prime \prime}$ & 2 & 175 & 23 \\
\hline C51 & $34^{\circ} 40^{\prime} 26^{\prime \prime}$ & $129^{\circ} 25^{\prime} 55^{\prime \prime}$ & 4 & 120 & 16 \\
\hline C52 & $34^{\circ} 38^{\prime} 26^{\prime \prime}$ & $129^{\circ} 23^{\prime} 37^{\prime \prime}$ & 3 & 180 & 40 \\
\hline C53 & $34^{\circ} 38^{\prime} 38^{\prime \prime}$ & $129^{\circ} 19^{\prime} 37^{\prime \prime}$ & 78 & 1050 & over \\
\hline C54 & $34^{\circ} 33^{\prime} 55^{\prime \prime}$ & $129^{\circ} 18^{\prime} 31^{\prime \prime}$ & 17 & 400 & 13 \\
\hline C55 & $34^{\circ} 32^{\prime} 6^{\prime \prime}$ & $129^{\circ} 20^{\prime} 33^{\prime \prime}$ & 2 & 56 & 48 \\
\hline C56 & $34^{\circ} 28^{\prime} 43^{\prime \prime}$ & $129^{\circ} 23 ' 39^{\prime \prime}$ & 7 & 25 & 25 \\
\hline C57 & $34^{\circ} 23^{\prime} 16^{\prime \prime}$ & $129^{\circ} 22^{\prime} 6^{\prime \prime}$ & 90 & 1480 & 28 \\
\hline C58 & $34^{\circ} 13^{\prime} 9^{\prime \prime}$ & $129^{\circ} 11^{\prime} 42^{\prime \prime}$ & 39 & 70 & 12 \\
\hline C59 & $34^{\circ} 19^{\prime} 1 "$ & $129^{\circ} 12^{\prime} 44^{\prime \prime}$ & 146 & 4 & 4 \\
\hline C60 & $34^{\circ} 18^{\prime} 25^{\prime \prime}$ & $129^{\circ} 13^{\prime} 26^{\prime \prime}$ & 19 & over & 162 \\
\hline C61 & $34^{\circ} 18^{\prime} 16^{\prime \prime}$ & $129^{\circ} 17^{\prime} 39^{\prime \prime}$ & 44 & over & over \\
\hline C62 & $34^{\circ} 18^{\prime} 51^{\prime \prime}$ & $129^{\circ} 16^{\prime} 48^{\prime \prime}$ & 3 & over & over \\
\hline C63 & $34^{\circ} 18^{\prime} 50^{\prime \prime}$ & $129^{\circ} 21^{\prime} 57^{\prime \prime}$ & 2 & 304 & 68 \\
\hline C64 & $34^{\circ} 22^{\prime} 18^{\prime \prime}$ & $129^{\circ} 22^{\prime} 39^{\prime \prime}$ & 2 & 390 & 188 \\
\hline C65 & $34^{\circ} 23^{\prime} 0^{\prime \prime}$ & $129^{\circ} 18^{\prime} 57^{\prime \prime}$ & 40 & 199 & 50 \\
\hline C66 & $34^{\circ} 21^{\prime} 49^{\prime \prime}$ & $129^{\circ} 14^{\prime} 37^{\prime \prime}$ & 11 & 21 & 9 \\
\hline C67 & $34^{\circ} 26^{\prime} 14^{\prime \prime}$ & $129^{\circ} 17^{\prime} 36^{\prime \prime}$ & 4 & over & over \\
\hline C68 & $34^{\circ} 27^{\prime} 4^{\prime \prime}$ & $129^{\circ} 18^{\prime} 55^{\prime \prime}$ & 4 & 530 & 47 \\
\hline C69 & $34^{\circ} 37^{\prime} 53^{\prime \prime}$ & $129^{\circ} 28^{\prime} 41^{\prime \prime}$ & 43 & 400 & 75 \\
\hline C70 & $34^{\circ} 37^{\prime} 44^{\prime \prime}$ & $129^{\circ} 28^{\prime} 32^{\prime \prime}$ & 4 & 30 & 9 \\
\hline C71 & $34^{\circ} 37^{\prime} 6 "$ & $129^{\circ} 28^{\prime} 44^{\prime \prime}$ & 3 & 450 & 44 \\
\hline C72 & $34^{\circ} 16^{\prime} 28^{\prime \prime}$ & $129^{\circ} 19^{\prime} 56^{\prime \prime}$ & 8 & over & 3 \\
\hline
\end{tabular}

aver $3000 \mathrm{~m}^{2}$. bover 500 individuals.

the shore tended to be lower than in inland populations $(120.5 \pm 39.3<172.9 \pm 36.5, F(2.591)=0.112, P=$ 0.268; no significant difference). Because the places where it could grow were more limited along the shore than inland and were surrounded by trees and the sea, it seemed that the shore populations were less likely to expand their distribution in the future. Particularly, isolated populations with few individuals were presumed to have lower fitness from inbreeding depression [37] [38] or Allee effect [39].

\subsection{Sequence Variations}

Sequence variations among populations in six of the 11 regions of amplified chloroplast DNA were confirmed using primers prepared from the Genbank registration sequence or universal primers. The intergenic spacer sequence of $t r n \mathrm{~L}-t r n \mathrm{~F}$ region distinguished $\mathrm{H} 2$ from other haplotypes by sequence variation in the number of repetitions (Table 3). Similarly, the sequence of the rpl32-trnL region distinguished H1 from other haplotypes by such variation. The sequence of the psbD-trn T region distinguished $\mathrm{H} 1, \mathrm{H} 2$, and $\mathrm{H} 3$ from other haplotypes by sequence variations in the number of repetitions and an insertion-deletion (indel) of 9 bases. The sequence of the trnQ-rps16 region distinguished $\mathrm{H} 2$ from other haplotypes by sequence variations in the number of repetitions and an indel of 13 bases, and distinguished $\mathrm{H} 1, \mathrm{H} 2$, and $\mathrm{H} 4$ from other haplotypes by three substitution sites. The sequence of the rps16-trnK region distinguished $\mathrm{H} 1$ and $\mathrm{H} 2$ from other haplotypes by sequence variations 


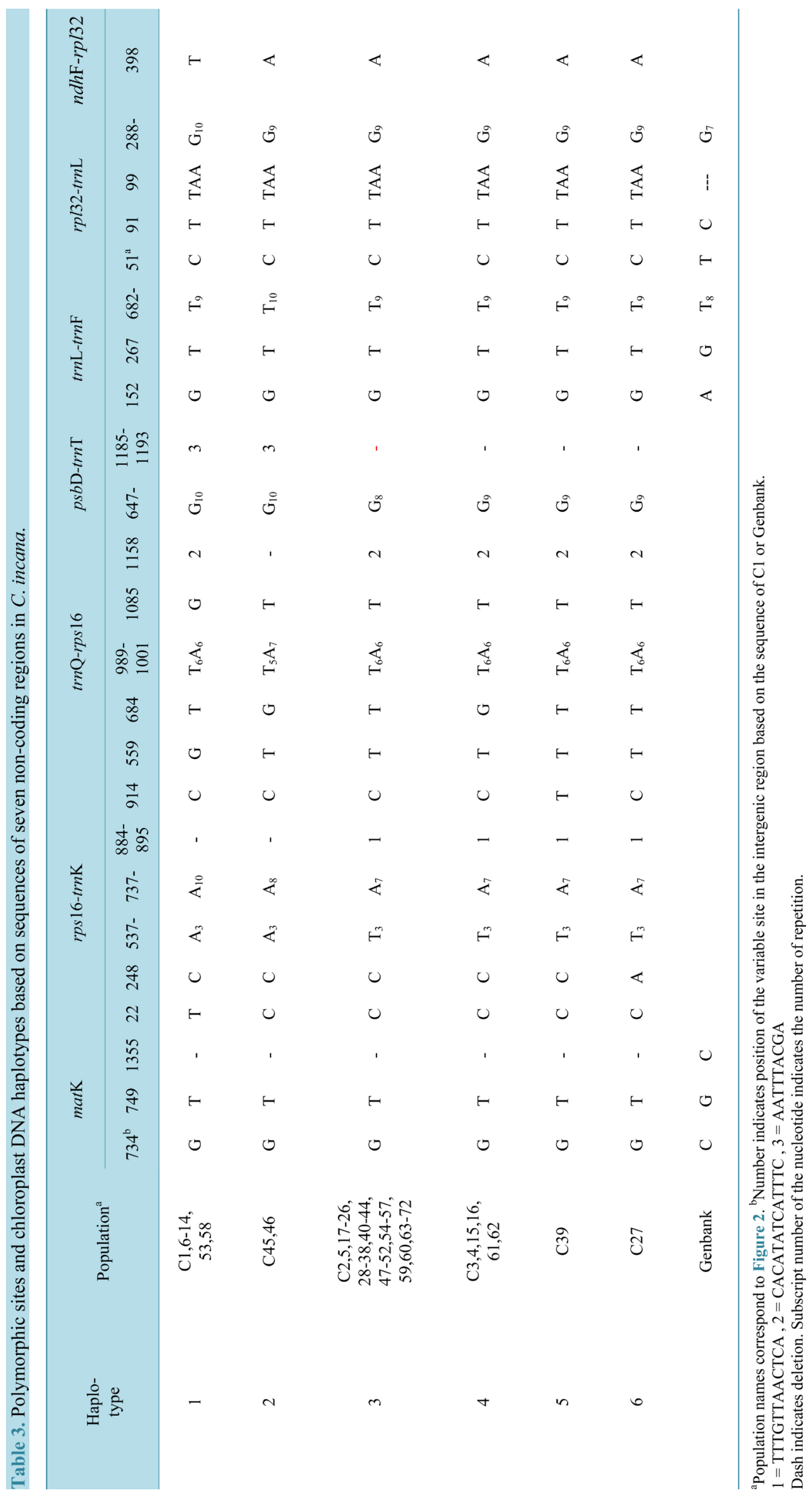


in the number of repetitions and an indel of 13 bases, and distinguished haplotypes besides $\mathrm{H} 3$ and $\mathrm{H} 4$ by four substitution sites. The sequence of $\mathrm{H} 1$ was different from other haplotypes in multiple sites. H4, H5 and H6 differed from $\mathrm{H} 3$ by sequence variations in a substitution site and the number of repetitions.

The numbers of polymorphic sites in each sequence region indicated a trend that was similar to the results of the numbers of polymorphic sites of each region according to [29]. Several substitution sites between Genbank registration sequences and those of study populations were confirmed in the matK, $\operatorname{trnL}-\mathrm{trnF}$ and $r p l 32-t r n \mathrm{~L}$ regions. However, there were no indications of substitution among the study populations in these sites. Because these regions were used for wider phylogenetic analyses, such as interspecific comparisons, than the regions with substitution among the study populations, the distribution of $C$. incana in Tsushima may have been relatively recent. On the other hand, the sequence of the ITS region in the nuclear DNA did not have clearly polymorphic sites among study populations.

Two haplotypes were shown mainly in the regions that confirmed sequence variation between populations (Figure 3). The border between H1 and H3 was located in the northern part of the south island (Figure 3), and sequence variations between the haplotypes were present at several sites (Table 3). The shortest straight line distance between populations of the difference haplotypes was approximately $3 \mathrm{~km}$ across the northwestern border and approximately $13 \mathrm{~km}$ across the northeastern border on the south island. Interestingly, H1, which was located on the south island, was found in a population in the northwest of the north island. This was a large population on the slope along a roadside near public facilities. Because of this local environment, we speculated that

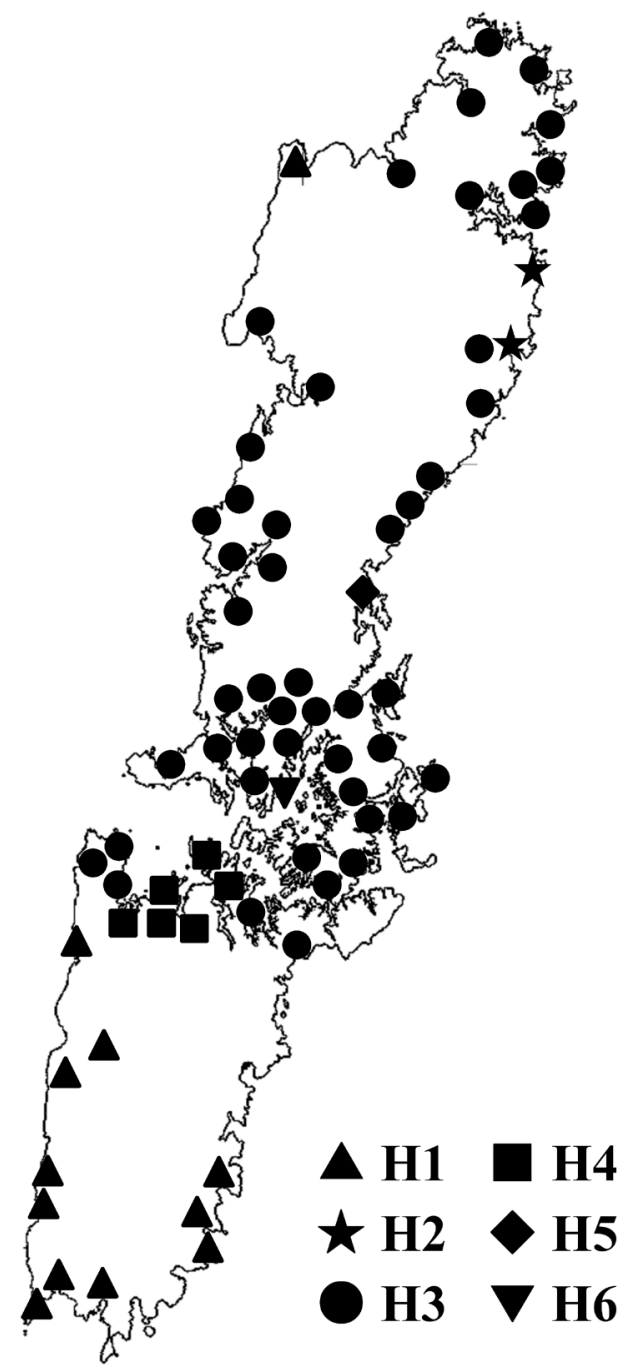

Figure 3. Geographic distribution of chloroplast DNA haplotypes detected in C. incana. 
this population was formed from soil used for construction that mixed in seeds of $C$. incana from some southern population, or planting after slope face spray constructions along a roadside. This suggested that there had been human influence on the distribution of $C$. incana in Tsushima. In addition, we confirmed the variation in the eastern side of the north island and parts of the central region.

Unlike chloroplast DNA, haplotype in the ITS regions of nuclear DNA did not present genetic a clear genetic structure in the sequence of substitution parts indicating the hetero model. If the sequences in other nuclear DNA regions beside the ITS region were similar among populations with different chloroplast DNA haplotypes, it could be that there is cross-pollination among all populations in Tsushima. In this case, it would be suggested that the present distribution of haplotypes was the result of pollination among populations from throughout the islands after the distribution and fragmentation of populations. Studies using other nuclear DNA regions or microsatellites would be necessary to determine whether this hypothesis is correct. If the genetic structure of the nuclear DNA in Tsushima was confirmed in regions other than the ITS region in accordance with the speculated cross-pollination among populations, the one northern population with a southern chloroplast DNA haplotype might cause introgression to occur by crossing with neighboring populations in the future.

\subsection{Phylogenetic Analyses}

Because of the limited variation in the intergenic regions where sequence variation can easily occur in chloroplast DNA, we cannot construct reliable family trees among haplotype of each population (Figure 4). Thus, the distribution was more likely to have developed relatively recently, so comparison to sequence variations in other natural habitat areas is necessary. The haplotype network in Figure 5 showed that the main northern haplotype (H3) was genetically different from the southern haplotype (H1). H4, H5, and H6 were speculated to have derived from $\mathrm{H} 3$ because they only vary by one base substitution and one site of repetition from H3. H4, which is distributed in the northern part of the south island, was suggested to have expanded after mutation from H3. Because H5 and H6 were confirmed in small populations that seemed to be unlikely to have seed dispersal to or from the shore, they were speculated to be derived by genetic drift from $\mathrm{H} 3$ after the present distribution was formed. In contrast to these haplotypes, the haplotype that expanded along the southern part of the south island did not have any derived haplotypes, so it was suggested that the distribution on the north island occurred earlier than on the south island. $\mathrm{H} 2$ had a very different sequence from $\mathrm{H} 1$ or H3. These populations may have represented

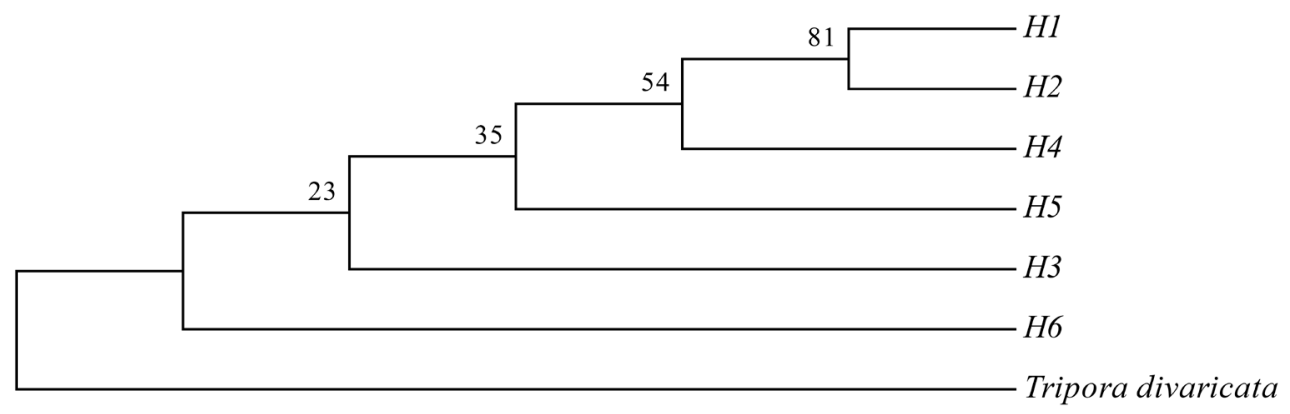

Figure 4. Neighbor-joining tree of chloroplast DNA haplotypes based on the sequences of seven non-coding regions in $C$. incana. Numbers below the branches indicate the bootstrap values.

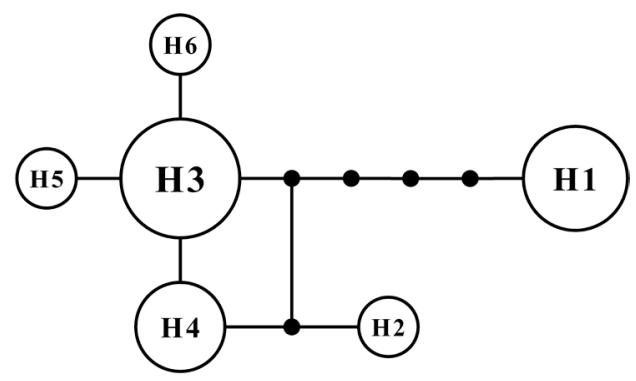

Figure 5. Haplotype network among all Tsushima haplotypes in C. incana. Haplotype numbers correspond to Table 3. Small circles in black indicate a substitution. 
early original variation because they did not seem to have been affected by human influence from their neighboring environments.

The different distribution of haplotypes in the northern and the southern islands in Tsushima suggested that the distribution might have expanded to north from glacial refugia on the south island, or that $C$. incana colonized the north and south islands in Tsushima at different times during the repeated northward and southward movement across the land bridge through glacial and interglacial cycles. In the former situation, there would be more differentiated haplotypes on the south island; however, the southern populations had only one haplotype, unlike the northern population. Furthermore, it seemed that the latter situation was likely because the southern haplotype was genetically different from northern haplotypes, but these data could not identify when the northern and southern populations had colonized Tsushima. To estimate these times, we would have to compare these populations with those on the Goto Islands and Kyushu mainland. Then, we might be able to estimate when $C$. incana expanded its distribution to Japan by studying wild individuals from the Korean Peninsula.

\section{Conclusion}

In conclusion, we confirmed the present natural environment of Caryopteris incana, which was an endangered species in Japan, and constructed its distribution map in Tsushima. In addition, we investigated the genetic structure among the populations in Tsushima based on chloroplast DNA sequences. Then, we confirmed that $C$. incana colonized the north and south islands at different times. However, we did not find a clear genetic structure from the nuclear DNA sequence. A population on the north island with the southern haplotype suggested that there might have been some human influence on the distribution of $C$. incana in Tsushima, and that this population might be able to cause introgression by crossing with neighborhood populations in the future. Additional comparisons of the genetic structure among natural populations outside Tsushima would offer useful information on the evolutionary history of $C$. incana.

\section{References}

[1] Darwin, C. (1859) On the Origins of Species by Means of Natural Selection. John Murray, London.

[2] Avise, J.C., Arnold J., Ball, R.M., Bermingham, E., Lamb, T., Neigel, J.E., Reeb, C.A. and Saunders, N.C. (1987) Intraspecific Phylogeography: The Mitochondrial DNA BRIDGe between Population Genetics and Systematics. Annual Reviews of Ecology and Systematics, 18, 489-522. http://dx.doi.org/10.1146/annurev.es.18.110187.002421

[3] Hewitt, G.M. (1996) Some Genetic Consequences of Ice Ages, and Their Role in Divergence and Speciation. Biological Journal of the Linnean Society, 58, 247-276. http://dx.doi.org/10.1111/j.1095-8312.1996.tb01434.X

[4] Medail, F. and Diadema, K. (2009) Glacial Refugia Influence Plant Diversity Patterns in the Mediterranean Basin. Journal of Biogeography, 36, 1333-1345. http://dx.doi.org/10.1111/j.1365-2699.2008.02051.x

[5] Comes, H.P. and Kadereit, J.W. (1998) The Effect of Quaternary Climatic Changes on Plant Distribution and Evolution. Trends in Plant Science, 3, 1360-1385. http://dx.doi.org/10.1016/S1360-1385(98)01327-2

[6] Qiu, Y.X., Fu, C.X. and Comes, H.P. (2011) Plant Molecular Phylogeography in China and Adjacent Regions: Tracing the Genetic Imprints of Quaternary Climate and Environmental Change in the World's Most Diverse Temperate Flora. Molecular Phylogenetics and Evolution, 59, 225-244. http://dx.doi.org/10.1016/j.ympev.2011.01.012

[7] Bai, W.N., Liao, W.J. and Zhang, D.Y. (2010) Nuclear and Chloroplast DNA Phylogeography Reveal Two Refuge Areas with Asymmetrical Gene Flow in a Temperate Walnut Tree from East Asia. New Phytologist, 188, 892-901. http://dx.doi.org/10.1111/j.1469-8137.2010.03407.x

[8] Aoki, K., Suzuki, T., Hsu, T.W. and Murakami, N. (2004) Phylogeography of the Component Species of BroadLeaved Evergreen Forests in Japan, Based on Chloroplast DNA Variation. Journal of Plant Research, 117, 77-94. http://dx.doi.org/10.1007/s10265-003-0132-4

[9] Nakanishi, H. (2010) Distribution and Ecology of Islet Biased Plants in northern Kyushu, Japan. Vegetation Science, 27, 1-9.

[10] Itow, S. (1997) A Review of Phyto- and Vegetation Geography in the Japan-Korea Strait Region. Bulletin of the Faculty of Liberal Arts, Nagasaki University, Natural Science, 38, 25-51.

[11] Nakanishi, H. (1996) Plant Species with Northbound Distribution in Western-Kyushu, Japan: Definition, Composition and Origin. Acta phytotaxonomica et Geobotanica, 47, 113-124.

[12] Abu-Asab, M.S., Cantino, P.D., Nowicke, J.W. and Sang, T. (1993) Systematic Implications of Pollen Morphology in Caryopteris (Labiatae). Systematic Botany, 18, 502-515. http://dx.doi.org/10.2307/2419422 
[13] Cantino, P.D., Wagstaff, S.J. and Olmstead, R.G. (1999) Caryopteris (Lamiaceae) and the Conflict between Phylogenetic and Pragmatic Considerations in Botanical Nomenclature. Systematic Botany, 23, 369-386. http://dx.doi.org/10.2307/2419511

[14] Gao, J. and Han, G. (1997) Cytotoxic Abietane Diterpenoids from Caryopteris incana. Phytochemistry, 44, 759-561. http://dx.doi.org/10.1016/S0031-9422(96)00609-7

[15] Gao, J., Igalashi, K. and Nukina, M. (1999) Radical Scavenging Activity of Phenylpropanoid Glycosides in Caryopteris incana. Bioscience, Biotechnology, and Biochemistry, 63, 983-988. http://dx.doi.org/10.1271/bbb.63.983

[16] Gao, J., Igalashi, K. and Nukina, M. (2000) Three New Phenylethanoid Glycosides from Caryopteris incana and Their Antioxidative Activity. Chemical and Pharmaceutical Bulletin, 48, 1075-1078. http://dx.doi.org/10.1248/cpb.48.1075

[17] Li, J. and Wang, Y. (2004) Synthesis of Trisaccharide of Incanoside from Caryopteris incana. Synthetic Communications, 34, 515-522. http://dx.doi.org/10.1081/SCC-120027292

[18] Zhao, D.P., Matsunami, K. and Otsuka, H. (2009) Iridoid Glucoside, (3R)-oct-1-en-3-ol Glycosides, and Phenylethanoid from the Aerial Parts of Caryopteris incana. Journal of Natural Medicines, 63, 241-247. http://dx.doi.org/10.1007/s11418-009-0317-9

[19] Chu, S.S., Liu, Q.Z., Zhou, L., Du, S.S. and Liu, Z.L. (2011) Chemical Composition and Toxic Activity of Essential Oil of Caryopteris incana against Sitophilus zeamais. African Journal of Biotechnology, 10, 8476-8480.

[20] Itow, S. and Kawasato, H. (1988) The Distribution and Ecology of Caryopteris incana Maxim. (Verbenaceae) in Western Kyushu, Japan. Hikobia, 10, 135-143.

[21] Itow, S., Kim, C.S., Kim, M.H., Kawasato, H. and Oh, J.G. (1993) Biogeography and Ecology of Caryopteris incana Maxim. (Verbenaceae) in Regions of Japan-Korea Strait. Bulletin of the Faculty of Liberal Arts, Nagasaki University, Natural Science, 34, 45-50.

[22] Environment Agency of Japan (2000) Threatened Wildlife of Japan, Red Data Book 2nd Edition. Japan Wildlife Research Center, 8, 521.

[23] Doyle, J.J. and Doyle, J.L. (1987) A Rapid DNA Isolation Procedure for Small Quantities of Fresh Leaf Tissue. Phytochemical Bulletin, 19, 11-15.

[24] Lassner, M.W., Peterson, P. and Yoder, J.I. (1989) Simultaneous Amplification of Multiple DNA Fragments by Polymerase Chain Reaction in the Analysis of Transgenic Plants and Their Progeny. Plant Molecular Biology Reporter, 7 , 116-128. http://dx.doi.org/10.1007/BF02669627

[25] Hilu, K.W. and Liang, H.P. (1997) The matK Gene: Sequence Variation and Application in Plant Systematics. American Journal of Botany, 84, 830-839. http://dx.doi.org/10.2307/2445819

[26] Shi, S., Du Y., Boufford, D.E., Gong, X., Huang, Y., He, H. and Zhong, Y. (2003) Phylogenetic Position of Schnabelia, a Genus Endemic to China: Evidence from Sequences of cpDNA matK Gene and nrDNA ITS Regions. Chinese Science Bulletin, 48, 1576-1580. http://dx.doi.org/10.1360/03wc0081

[27] Taberlet, P., Gielly, L., Pautou, G. and Bouvet, J. (1991) Universal Primers for Amplification of Three Non-Coding Regions of Chloroplast DNA. Plant Molecular Biology, 17, 1105-1109. http://dx.doi.org/10.1007/BF00037152

[28] Drew, B.T. and Sytsma, K.J. (2011) Testing the Monophyly and Placement of Lepechinia in the Tribe Mentheae (Lamiaceae). Systematic Botany, 34, 1038-1049. http://dx.doi.org/10.1600/036364411X605047

[29] Shaw, J., Lickey, E.B., Schilling, E.E. and Small, R.L. (2007) Comparison of Whole Chloroplast Genome Sequences to Choose Noncoding Regions for Phylogenetic Studies in Angiosperms: The Tortoise and the Hare III. American Journal of Botany, 94, 275-288. http://dx.doi.org/10.3732/ajb.94.3.275

[30] Drew, B.T. and Sytsma, K.J. (2012) Phylogenetics, Biogeography, and Staminal Evolution in the Tribe Mentheae (Lamiaceae). American Journal of Botany, 99, 933-953. http://dx.doi.org/10.3732/ajb.1100549

[31] White, T.J., Bruns, T., Lee, S. and Taylor, J. (1990) Amplification and Direct Sequencing of Fungal Ribosomal RNA Genes for Phylogenetics. In: Innis, M.A., Gelfand, D.H., Shinsky, J.J. and White, T.J., Eds., PCR Protocols: A Guide to Methods and Applications, Academic Press, Inc., New York, 315-322. http://dx.doi.org/10.1016/b978-0-12-372180-8.50042-1

[32] Steane, D.A., Scotland, R.W., Mabberley, D.J. and Olmstead, R.G. (1999) Molecular Systematics of Clerodendrum (Lamiaceae): ITS Sequences and Total Evidence. American Journal of Botany, 86, 98-107. http://dx.doi.org/10.2307/2656958

[33] Huang, M., Crawford, D.J., Freudenstein, J.V. and Cantino, P.D. (2008) Systematics of Trichostema (Lamiaceae): Evidence from ITS, ndhF, and Morphology. Systematic Botany, 33, 437-446. http://dx.doi.org/10.1600/036364408784571554

[34] Hall, T.A. (1999) BioEdit: A User-Friendly Biological Sequence Alignment Editor and Analysis Program for Windows 95/98/NT. Nucleic Acids Symposium Series, 41, 95-98. 
[35] Tamura, K., Stecher, G., Peterson, D., Filipski, A. and Kumar, S. (2013) MEGA6: Molecular Evolutionary Genetics Analysis Version 6.0. Molecular Biology and Evolution, 30, 2725-2729. http://dx.doi.org/10.1093/molbev/mst197

[36] Huson, D.H. (1998) Splitstree: Analyzing and Visualizing Evolutionary Data. Bioinformatics, 14, 68-73. http://dx.doi.org/10.1093/bioinformatics/14.1.68

[37] Charlesworth, D. and Charlesworth, B. (1987) Inbreeding Depression and Its Evolutionary Consequences. Annual Review of Ecology and Systematics, 18, 237-268. http://dx.doi.org/10.1146/annurev.es.18.110187.001321

[38] Keller, L.F. and Waller, D.M. (2002) Inbreeding Effects in Wild Populations. Trends in Ecology and Evolution, 17, 230-241. http://dx.doi.org/10.1016/S0169-5347(02)02489-8

[39] Stephens, P.A., Sutherland, W.J. and Freckleton, R.P. (1999) What Is the Allee Effect? Oikos, 87, 185-190. http://dx.doi.org/10.2307/3547011 